Indah Raya Permata, graduate student of the Magister of Management Sciences, Faculty of Economics, Sriwijaya University, Palembang

e-mail: indah.irpk@gmail.com

Wahab Zakaria, Ph.d of Economics, Marketing Management Economics, Faculty of Economics, Sriwijaya University, Palembang

ORCID ID: 0000-0003-1036-023x

e-mail: zkwahab@yahoo.com

Muchsin Saggaf Shihab, Ph. D of Economics, Marketing Management Economics, Bakrie University, South Jakarta

e-mail: muchsin.shihab@bakrie.ac.id

Hanafi Agustina, Ph.D of Economics, Economics in Human Resource Management, Faculty of Economics, Sriwijaya University, Palembang

ORCID ID: 0000-0003-2966-3943

e-mail: tinahanafi@ymail.com

\title{
The Effects of Mediating Consumer-Based Brand Equity and Moderate Income on Endorser Credibility with Buying Interest
}

Abstract. Intriduction. The purpose of this study is to determine the moderating effect of consumer-based brand equity and income moderation on endorsers' credibility with buying interest. Respondents in this study were internet users who had seen Safi endorsements on social media -Youtube and Instagram - but had not yet purchased the product. The research design used was systematic random sampling. This study used 240 samples. Data was collected using a questionnaire distributed online through Instagram. Analysis of this study used the Partial Least Square (PLS) program.

Purpose. Thus, to know the Effect of Endorser Credibility on Buying Interest, The Effect of Endorser Credibility on Consumer-Based Brand Equity, The Effect of Consumer-Based Brand Equity on Buying Interests, The Effect of Consumer-Based Brand Equity on Buying Interests, Income moderates the influence of endorsement credibility on buying interest.

Results. The results of this study indicated that consumer-based brand equity mediated the endorser credibility. In addition, the income variable also moderated the relationship.

Conclusion. The results of the research are described in the previous paragraph. There are several conclusions as Endorser credibility had a significant effect on buying interest, Endorser credibility had a significant effect on consumer-based brand equity, Consumer-based brand equity had a significant effect on buying interest, Consumer-based brand equity mediated the relationship between endorsement credibility and buying interest, Income moderates the effect of endorsement credibility on buying interest.

Keywords: consumer-based brand equity, income, credibility.

Індах Рая Пермата, аспірант, факультет економіки, Університет Шривіджая, Палембанг, Індонезія

Вахаб Закаріа, кандидат економічних наук, факультет економіки, Університет Шривіджая, Палембанг, Індонезія Індонезія

Мучсін Саггаф Шіхаб, кандидат економічних наук, Університет Бакрі, Південна Джакарта,

Ханафі Агустіна, кандидат економічних наук з управління персоналом, факультет економіки, Університет Шривіджая, Палембанг, Індонезія

\section{Вплив опосередкованого споживчого капіталу бренда та помірного доходу на надійність користувачів із купівельним інтересом}

Анотація. Дослідження спрямоване на визначення стримуючого впливу споживчого капіталу бренду та помірності доходів на кредитоспроможність індосантів із зацікавленням у купівлі. Респонденти цього дослідження були користувачами Інтернету, які бачили Sаfі-індосаменти у соціальних мережах Үоиtиbe та Instagram, aле ще не придбали продукт. Дослідження базувалося на основі систематичної вибірки. Зразки, використані в цьому дослідженні, за кількістю становили 240. Збір даних здійснювався за допомогою анкети, розповсюдженої в мережі Інтернет через історію Instagram. Для аналізу даних цього дослідження використовувалась програма Partial Least Square (PLS). 
Отже, метою дослідження було визначити: вплив довіри індосанта на зацікавленість покупця; вплив довіри індосанта на капітал бренду, що базується на споживачеві; вплив капіталу бренду, що базується на споживачеві, на інтереси покупия; яким чином дохід зменшує вплив індосаментності на купівельний інтерес.

Результати дослідження свідчать, що власний бренд, заснований на споживачах, опосередковував довіру до індосанта. Крім того, змінна доходу також модерувала відносини.

За результатами дослідження можна зробити декілька висновків: довіра до індосанту мала значний вплив на купівельний інтерес; довіра до індосатора мала значний вплив на бренд, орієнтований на споживача; власний бренд, що базується на споживачах, суттєво вплинув на купівельний інтерес; власний бренд, що базується на споживачах, опосередкував зв'язок між підтвердженням довіри та купівельним інтересом; дохід зменшує вплив індосаментності на купівельний інтерес.

Ключові слова: споживчий капітал бренду, дохід, надійність.

Stetement of the problem. The increasing popularity of social media has been able to defeat conventional marketing channels such as print, television and radio. It encourages marketers to use influencer services to market their products / services on social media such as Youtube, Instagram, Facebook, Twitter and others through endorsement services. Influencer is a term for people who are considered capable of influencing people. While the term endorse is common among the public in describing promotional activities of products or services carried out by famous or influential figures such as artists or key opinion leaders who are also often referred to as buzzers, celebrities, bloggers and so on.

Fantastic income and endorse goods are the main attraction for internet users and influencers becomes new ideal profession. Not only for ordinary internet users who later became celebrities (celebrities only on social media), the social media influencer profession was also in demand by internet users who began their careers as artists. For example in Indonesia, there are many celebrities who reap profits from becoming social media influencers, such as Raffi Ahmad, Nagita Slavina, Gissela Anastasia, Luna Maya, Zaskia Adya Mecca, Ayudia Bing Slamet and many more.

It seems to be the spotlight for Brand Safi. Safi is a brandskin care that carries the halal theme from Malaysia. Safi entered the Indonesian market in May 2018, challenging Indonesia's incumbent skin care brand, Wardah. The use of endorsement services from 40 influencers while at the same time making Safi optimistic allowed them to enter the Indonesian skin care market.

Most marketers consider endorsement as the most effective promotional instrument. Endorsement, which is a part of influencer marketing, is a method of increasing brand awareness (Pradhan et al (2014) (SociaBuzz; 2018), educating target consumers, increasing followers, as search engine optimization (SociaBuzz; 2018), and developing consumer-based brand equity (CBBE) (Keller; 1993 and Spry et al; 2011).

As a benchmark for branding strength, Top Brand Indonesia is an award for brands that are categorized as top brands. Based on the official Top Brand Awards website, Top Brand awards are given to brands in certain product categories that meet criteria based on consumer choice. The parameters used to determine the person with the Top Brand title are Top of Mind Awareness, based on the brand that was first mentioned by the respondent, Last Used, which is based on the brand used by the respondent, and Future Intention, based on the brand that will be used in the future. The parameters and criteria were tested in the Frontier Consulting Group survey conducted on approximately 12,000 consumers aged between 15-65 years through socio-economic status (SES) by looking at the average family expenditure per month between SES D (expenditure routine Rp.700,000 to Rp.1,000,000) up to SES A (expenditure in Sumatra over Rp.3,000,0000) (Nielsen, 2016) in eleven major cities in Indonesia, namely Jakarta, Bandung, Semarang, Surabaya, Medan, Makassar, Pekanbaru, Balikpapan, Denpasar, Palembang, and Samarinda (www.topbrand-award.com).

According to Skin Care Category Director of Wipro Unza Indonesia, Safi's sales increased 5-fold in the third quarter of 2018, despite not being included in the Top Brand Indonesia list, still having a small market share, and only entering the Indonesian market in the first quarter of 2018, This shows a tremendous increase in the sale of Safi products. Increased sales of Safi products can be used as a representation of the many consumers who have decided to buy Safi products even though the brand equity that has been built has not been strong.

Furthermore, the results of voting and preliminary interviews conducted after 30 respondents had watched Endorsement Safi's video showed that $44 \%$ of respondents said they were not interested in purchasing Safi's products. This shows that the endorsement carried out by Safi has not succeeded in maximizing the buying interest.

This study aimed to investigate more deeply the relationships between various factors. These factors were examined by analyzing the endorsement relationship, which was essentially based on one's strength in influencing others in the marketing context to increase purchases. This study would like to reveal endorsement's relationship to increasing consumer-based brand equity (CBBE) and the effect of interest in moderating influence opinion.

Eventhough there has been a lot of research on the influence and relationships between the credibility of endorsers, consumer-based brand equity, and buying interest, the phenomenon that occurred with Safi made researchers interested in further researching these variables. Many studies support the strong positive influence of an endorser's credibility on buying interest, including research conducted by Dwivedi et al (2015) and Setiawan (2018). In addition, Amos et al (2008) stated that the credibility of endorsers is the most influential effect on the effectiveness of using endorsers. Trust, expertise, 
and attractiveness of celebrities are the effects of endorsers that have the most influence on brand attitudes and advertisingattitudes, including buying interest.

In contrast to these studies, Samat et al (2016) in their study found that endorsers' credibility had a weak impact on buying interest.

Another thing that needs to be highlighted is the role of moderating income. As expressed by one of the 30 respondents interviewed previously. The respondent stated that he was not interested in buying Safi products advertised by influencers because of the income (income) they had. Low opinion will have an impact on the amount of a buyer's budget that can be used to buy skin care. In addition, although there have been many studies examining the effect of moderating income, the authors have not found a study that examines the effect of moderating income in the relationship between credibility of endorsers and buying interest.

\section{Theoretical review.}

\section{Endorser Credibility}

Many studies reveal that the main determinant of the endorser effect is the perceived credibility of an endorser by consumers (Ohanian, 1990; Amos, 2008). Endorser credibility refers to the extent to which they are considered credible (Ohanian, 1990). Basically, there is no dominant theory in the academic literature that explains the selection criteria for endorsers. In addition, the credibility of the endorser has been investigated and applied in various ways. But in this study, to examine the relationship between constructs of the influence of KOLendorsement represented by endorser credibility by adopting the concept of credibility endorser Ohanian (1990) which has been used by many researchers before. According to the concept, the credibility of the endorser consists of three main characteristics which then become dimensions in the endorser credibility variable as explained below:

\section{Attractiveness}

Refers to consumer perceptions of the physical attractiveness of endorsers

\section{Trustworthiness}

Refers to honesty, integrity, and the level of consumer confidence in an endorser.

\section{Expertise}

Is the consumer's perception of the knowledge, experience, or ability of the endorser with relation to the supported product.

\section{Buying Interest}

Buying interest refers to the possibility of consumers planning or willing to buy products or certain services in the future (Kim et al, 2007; Wang et al, 2013; Wu et al, 2011). And referring to the desire to buy is broadly defined as the possibility of consumers buying products or services (Dodd and Supa 2011; Sam and Tahir 2009). Diallo (2012) argues that buying interest refers to the effort to buy a product or service. While according to Schiffman and Kanuk (2008), interest is a psychological activity that arises because of the feelings and thoughts of a desired item or service. Interest does not appear in someone's mind and then becomes the cause for not buying a product or service. Sedangkan Spears \& Singh (2004) mendefinisikannya sebagai rencana sadar yang dibuat oleh individu untuk melakukan upaya membeli merek atau purchase decision.Engel et al (1995) argue that buying interest is a driving force or an intrinsic motive that is able to encourage someone to pay attention spontaneously, naturally, easily, without coercion and selectively on a product to then make a buying decision.

3. Consumer-Based Brand Equity

Paradigm and the importance of brand equity in marketing theory have continued to be the focus of research for more than two decades (Davcik et al. 2015) and are seen as multidimensional constructs (Aaker; 1991). Simon and Sullivan (2008) define brand equity as cash flow additions to branded products over nonbranded products. Then Aaker (1997) states that brand equity is a set of brand assets and liabilities related to a brand, specifically names and symbols that increase or decrease the value provided by goods or services to companies or customers. Whereas Kotler and Keller (2008) say that brand equity is the added value given to products and services. Brand equity can be seen from the way consumers think, act, and feel in relation to the brand.

4. Income

Consumer demographic information is the most frequently used characteristic in the identity of respondents in the marketing field (Homburg \& Giering, 2001; Mittal \& Kamakura, 2003; Ranaweera, McDougall, \& Bansal, 2005). Schiffman \& Kanuk (2008) suggest that the easiest, most effective, and efficient way to plan market segmentation is through consumer demographic information. One defining piece of information is income. Itis because income affects the purchasing power and influences a person's behavior, motives, habits, and tastes.

The income level is the income received in 1 month, using the ratio scale. Referring to Kasri's research (2013), in this study income was divided into two groups, namely:

1. Group 1 (Middle to lower income), namely: <Rp.1,000,000 / month,> Rp.1,100,000 - Rp.5,000,000 / month, Rp.5,100,000 - Rp.10,000,000 / month

2. Group 2 (middle to upper income), namely: Rp.10,100,000 - Rp.20,000,000 / month,> Rp.20,000,000 / month

Conceptual Framework. Based on the description of the relationship between variables and previous research above, a theoretical thought is obtained with the following description: 


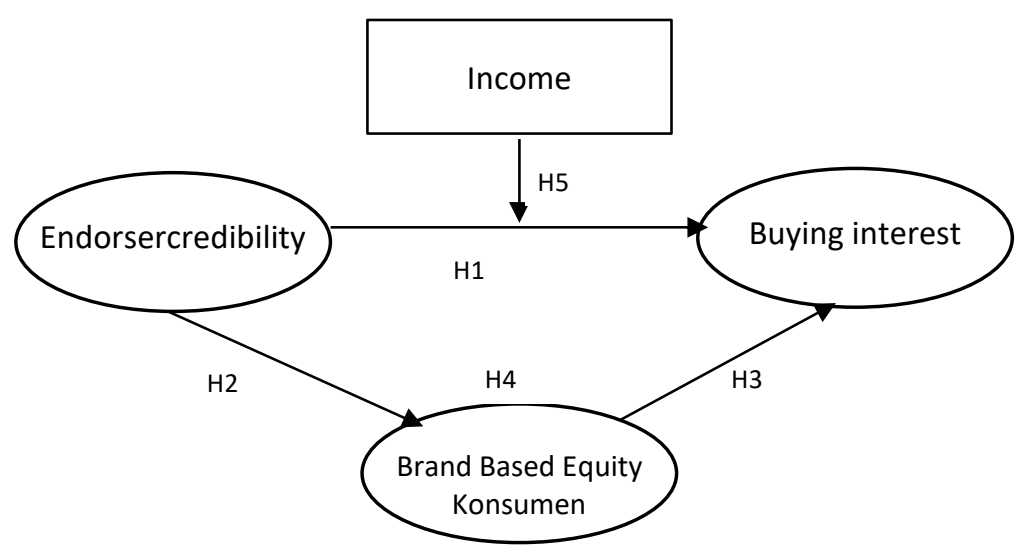

Fig 1. Framework

Based on the results of previous research and the theoretical framework, the hypotheses proposed are as follows:

H1: Endorser credibility has a significant effect on Consumer-based brand equity

$\mathrm{H} 2$ : Consumer-based brand equity has a significant effect on buying interest

H3: Endorser credibility has a significant effect on buying interest

H4: Consumer-based brand equity mediates the relationship between endorser and credibility interest in buying

H5: Income moderates the influence of endorsement credibility on buying interest

Research methods. The scope of research. This study examined the relationship between endorser credibility variables, consumer-based brand equity and buying interest, and also investigated the effect of the mediating on consumer-based brand equity and opinion in moderating the relationship. The Safi brand in Indonesia was the subject of the research.

Type of Data

In this study, the quantitative data used by the researchers were obtained from scores of consumer answers as respondents obtained from the research questionnaire.

Data source

The data sources used in this study were primary data. Primary data collection was carried out by distributing questionnaires to consumers shopping online in Indonesia to examine their behaviors in making purchases. The author distributed questionnaires to respondents via Google Form through Tasya Farasya's Instagram social media. Tasya Farasya is one of the beauty KOL endorser Safi who has the most YouTube subscribers and Instagram followers compared to the other KOL Safi. Tasya Farasya has 2.1 million Youtube subscribers and 1.9 million Instagram followers.

Population

The population in this study was all consumers of internet users in Indonesia who had seen endorse Safi ads on social media-both Youtube and Instagram-but had never bought these products.

\section{Samples}

In this study, the population was scattered and difficult to know for sure. The study used 24 indicators, according to the opinion of Hair et al., 2010, which argues that the appropriate sample size is 5 to 10 times the indicator. So ideal samples were 120 to 240 respondents. Therefore the samples used in this study included 240 respondents to get maximum results.

Data analysis

Descriptive Analysis

In this study, descriptive analysis was carried out using the frequency of respondents' answers regarding the variables given, namely endorser credibility variables, purchase interest variables, consumer-based brand equity variables, and income moderation variables.

Quantitative Analysis

1. InstrumentTest

Validity test

A questionnaire is declared valid when the question in the questionnaire is able to reveal something that will be measured by the questionnaire. In determining whether or not an item is worthy of being used, the significance test of the correlation coefficient is usually carried out at a significance level of 0.05 , which means that an item is considered valid when it has a significant correlation with the total score. The minimum requirement for a questionnaire item is considered valid when its validity index $\geq 0.3$ (Sugiyono, 2016). Therefore, all statements that have a correlation level below 0.3 must be corrected because they are considered invalid.

Reliability Test

According to Sugiyono (2016) Instruments are said to be reliable when the instrument is used several times to measure the same object and is able to produce the same data. A reliability test can be done using the Cronbach's alpha statistical technique (Arikunto, 2006). Instruments are said to be reliable when they have a value>0.60. High and low reliability is indicated by a number called the reliability coefficient, with a range of $0-1$. The closer the reliability coefficient is to 1 , the more reliable the measuring instrument.

Structural Equation Modelling- Partial Least Square (Sem- Pls) 
This study used partial regression analysis (Partial Least Square ( PLS) to test the five proposed hypotheses. Each hypothesis wasanalyzed using Smart PLS 2.0 software to test the relationships between variables.

The PLS method was chosen based on the consideration that in this study there were three latent variables formed with formative indicators and form mediating effects and the presence of one observed variable that forms as moderating effect. The formative model assumes that the construct or latent variable influences the direction of the causality relationship from construct to indicator or manifest Ghozali (2006). Ghozali (2006) further states the formative model assumes that indicators affect the construct, where the direction of the causal relationship is from the indicator to the construct.

Discussion. Validity test.

Table 1. Validitas-1 Test

\begin{tabular}{|c|c|c|c|c|}
\hline & $\begin{array}{l}\text { Scale Mean if } \\
\text { Item Deleted }\end{array}$ & $\begin{array}{c}\text { Scale } \\
\text { Variance if } \\
\text { Item Deleted }\end{array}$ & $\begin{array}{l}\text { Corrected } \\
\text { Item-Total } \\
\text { Correlation }\end{array}$ & $\begin{array}{c}\text { Cronbach's } \\
\text { Alpha if Item } \\
\text { Deleted }\end{array}$ \\
\hline \multicolumn{5}{|c|}{ Endorser credibility } \\
\hline KE1 & 99,48 & 105,171 & ,380 & ,937 \\
\hline KE2 & 99,04 & 103,664 & 394 & 937 \\
\hline KE3 & 99,77 & 102,537 & ,451 & ,936 \\
\hline KE4 & 99,02 & 101,489 & ,596 & 934 \\
\hline KE5 & 99,86 & 101,494 & ,533 & 935 \\
\hline KE6 & 100,12 & 102,394 & ,422 & 937 \\
\hline KE7 & 99,83 & 103,520 & ,434 & 936 \\
\hline KE8 & 99,76 & 102,628 & 411 & 937 \\
\hline KE9 & 99,04 & 101,158 & 683 & 933 \\
\hline \multicolumn{5}{|c|}{ Income } \\
\hline$P$ & 100,08 & 103,566 & ,518 & 935 \\
\hline \multicolumn{5}{|c|}{ Brand Equity } \\
\hline EM1 & 99,20 & 103,346 & ,404 & 937 \\
\hline EM2 & 99,05 & 99,110 & 754 & 932 \\
\hline EM3 & 99,43 & 101,543 & ,576 & 934 \\
\hline EM4 & 99,03 & 99,488 & ,667 & 933 \\
\hline EM5 & 99,31 & 99,295 & 797 & 932 \\
\hline EM6 & 99,28 & 100,070 & 721 & 932 \\
\hline EM7 & 99,37 & 100,325 & 677 & 933 \\
\hline EM8 & 99,48 & 99,037 & 661 & ,933 \\
\hline EM9 & 99,48 & 98,334 & 697 & 933 \\
\hline EM10 & 99,10 & 101,073 & 623 & 934 \\
\hline EM11 & 98,98 & 99,380 & ,765 & 932 \\
\hline EM12 & 98,92 & 101,541 & ,688 & 933 \\
\hline
\end{tabular}


Електронне наукове фахове видання з економічних наук “Modern Economics», №16 (2019), 11-20 https://modecon.mnau.edu.ua | ISSN 2521-6392

Continuation of Table 1

\begin{tabular}{|c|c|c|c|c|}
\hline \multicolumn{5}{|c|}{ Buying interest } \\
\hline MB1 & 99,02 & 98,067 &, 715 &, 932 \\
\hline MB2 & 99,01 & 98,096 &, 750 &, 932 \\
\hline MB3 & 99,64 & 99,102 &, 555 &, 935 \\
\hline
\end{tabular}

Source: Questionnaire data processed with SPSS, 2019

Based on Table 1, the validity test shows the value of Brand Equity and PBuying Interest variable, so the Corrected Item-Total Correlation> 0.3 in all questions resulting data can be analyzed further. Reliability Test. (items) in the Endorser Credibility variable, Revenue,

Table 2. Reliability Test. Item-Total Statistics

\begin{tabular}{|l|c|c|c|c|}
\hline \multicolumn{1}{|c|}{ Variable } & $\begin{array}{c}\text { Scale Mean if } \\
\text { Item Deleted }\end{array}$ & $\begin{array}{c}\text { Scale Variance } \\
\text { if Item Deleted }\end{array}$ & $\begin{array}{c}\text { Corrected Item- } \\
\text { Total } \\
\text { Correlation }\end{array}$ & $\begin{array}{c}\text { Cronbach's Alpha } \\
\text { if Item Deleted }\end{array}$ \\
\hline Endorser credibility & 12,1542 & 1,313 &, 846 &, 826 \\
\hline Income & 12,6579 & 1,061 &, 760 &, 863 \\
\hline Brand Equity & 11,7301 & 1,385 &, 895 &, 901 \\
\hline Buying Interest & 11,7190 & 1,257 &, 638 &, \\
\hline
\end{tabular}

Source: Questionnaire data processed with SPSS, 2019

Based on Table 2, it shows that the reliability test with Cronbach's Alpha value> 0.60 all questions (items) on all Partial Least Square Analysis (PIs) variables were reliable.

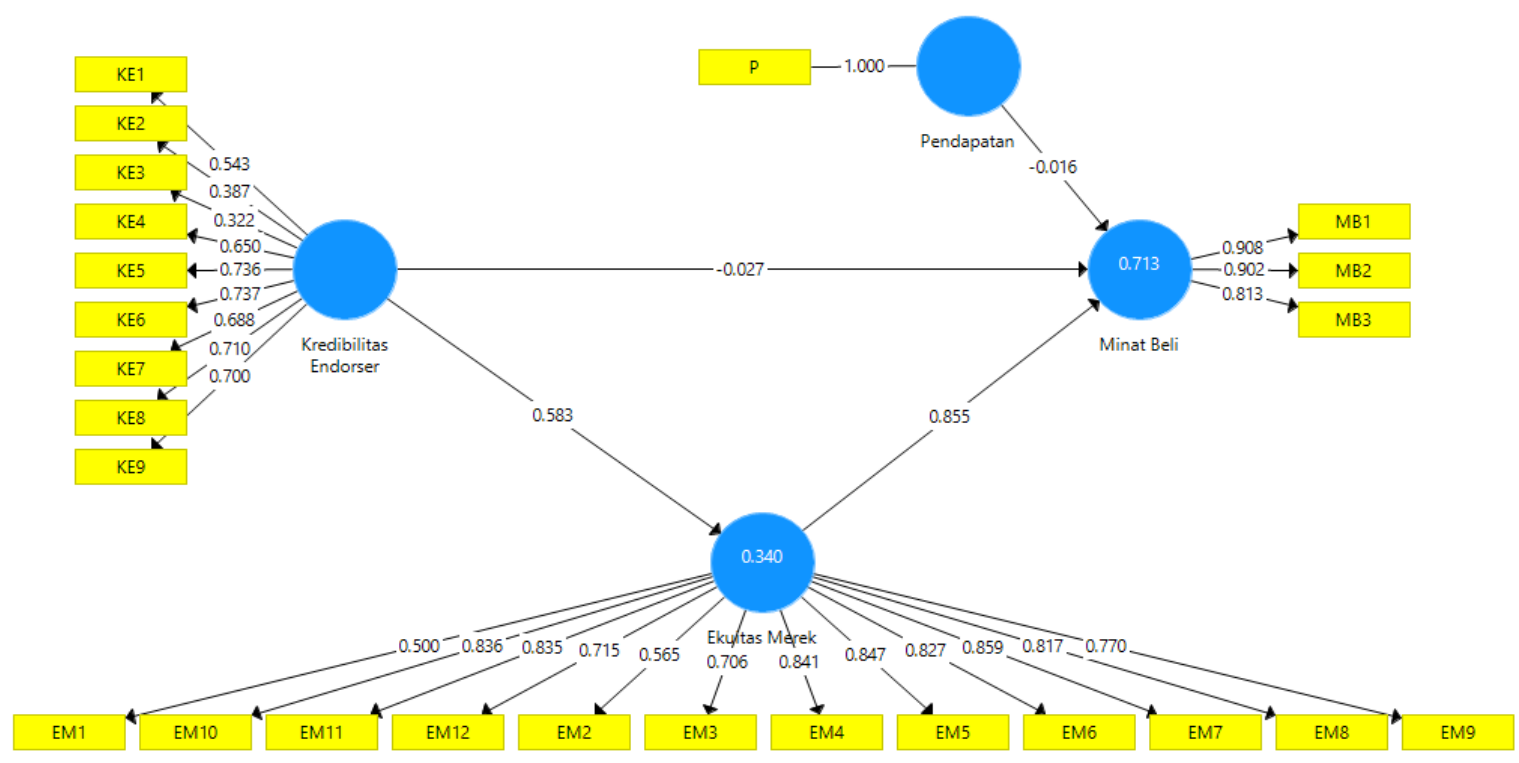

Fig 2. Measurement Model

Measurement Model Analysis. In using SEM-PLS, it is necessary to examine the reliability of indicators used as measuring instruments for latent variables. The reliability of an indicator can be received if the indicator reliability value is $>0.7$. The reliability value of each indicator can be calculated by squaring the outer loading value generated by each indicator after running the PLS algorithm using SmartPLS Software. 
Електронне наукове фахове видання з економічних наук "Modern Economics», №16 (2019), 11-20 https://modecon.mnau.edu.ua | ISSN 2521-6392

\begin{tabular}{|c|c|c|c|c|}
\hline \multicolumn{5}{|c|}{ Table 3. Indicator Reliability Check Results } \\
\hline Variables & Indicators & Outer Loading & $\begin{array}{l}\text { Indicator Reliability } \\
\text { Value }\end{array}$ & Note \\
\hline \multirow{9}{*}{ Endorser credibility } & KE1 & 0,858 & 0,736 & Reliable \\
\hline & KE2 & 0,839 & 0,704 & Reliable \\
\hline & KE3 & 0,853 & 0,728 & Reliable \\
\hline & KE4 & 0,841 & 0,708 & Reliable \\
\hline & KE5 & 0,827 & 0,684 & Not reliable \\
\hline & KE6 & 0,849 & 0,722 & Reliable \\
\hline & KE7 & 0,852 & 0,725 & Reliable \\
\hline & KE8 & 0,533 & 0,284 & Not reliable \\
\hline & KE9 & 0,462 & 0,214 & Not reliable \\
\hline Income & $P$ & 1,00 & 1,00 & Reliable \\
\hline \multirow{12}{*}{ Brand Equity } & EM1 & $-0,096$ & 0,009 & Not reliable \\
\hline & EM10 & 0,865 & 0,747 & Reliable \\
\hline & EM11 & 0,860 & 0,739 & Reliable \\
\hline & EM12 & 0,756 & 0,571 & Not reliable \\
\hline & EM2 & $-0,093$ & 0,009 & Not reliable \\
\hline & EM3 & $-0,142$ & 0,020 & Not reliable \\
\hline & EM4 & $-0,110$ & 0,012 & Not reliable \\
\hline & EM5 & 0,850 & 0,722 & Reliable \\
\hline & EM6 & 0,848 & 0,719 & Reliable \\
\hline & EM7 & 0,869 & 0,755 & Reliabel \\
\hline & EM8 & 0,808 & 0,652 & Not reliable \\
\hline & EM9 & 0,767 & 0,588 & Not reliable \\
\hline \multirow{3}{*}{ Buying interest } & MB1 & 0,909 & 0,827 & Reliable \\
\hline & MB2 & 0,908 & 0,825 & Reliable \\
\hline & MB3 & 0,803 & 0,645 & Not reliable \\
\hline
\end{tabular}

Source: Processed Data, 2019

Based on Table 3. not all indicators meet the indicator reliability requirements $>0.7$. The Endorser Credibility variables are indicators KE5, KE8 and KE9. The Brand Equity Variables are indicators EM1, EM2, EM3, EM4,
EM8, and EM12. Whereas in the Buying Interest Variable, the MB3 indicator should beremovedbecause it did not meet the indicator reliability requirements. 
Електронне наукове фахове видання з економічних наук "Modern Economics», №16 (2019), 11-20 https://modecon.mnau.edu.ua | ISSN 2521-6392

\begin{tabular}{|c|c|c|c|c|c|c|c|c|}
\hline \multirow[t]{2}{*}{ Mean, STDEV, T-Values, P-Values } & Keyakinan Interval & 圆 & Keyakinan Interval Bias & -Dikoreksi & Sampel & Salin ke Clipboard: & Format Excel & Format $R$ \\
\hline & Sampel Asli (0) & & Rata-rata Sampel (M) & \multicolumn{2}{|c|}{ Standar Deviasi (STDEV) } & T Statistik (| O/STDEV & \multicolumn{2}{|c|}{ P Values } \\
\hline Ekuitas Merek $>$ Minat Beli & \multicolumn{2}{|l|}{-2.971} & \multicolumn{2}{|l|}{-2.966} & 0.254 & 11.702 & \multicolumn{2}{|c|}{0.000} \\
\hline Kredibilitas Endorser -> Ekuitas Merek & \multicolumn{2}{|l|}{0.991} & \multicolumn{2}{|l|}{0.991} & 0.001 & 690.476 & \multicolumn{2}{|c|}{0.000} \\
\hline Kredibilitas Endorser -> Minat Beli & \multicolumn{2}{|l|}{3.801} & \multicolumn{2}{|l|}{3.796} & 0.239 & 15.881 & \multicolumn{2}{|c|}{0.000} \\
\hline
\end{tabular}

Hypothesis Test Based on Latent Variables. The Tstatistics value was used to assess the significance of the relationship between latent variables and other latent variables, depending on the significance value used, namely:
$-10 \%$ significance level, the minimum T-Statistics value is 1.65

$-5 \%$ significance level, the minimum T-Statistics value is 1.96

$-1 \%$ significance level, the minimum T-Statistics value is 2.58 .

Table 4. HypothesesTest of Structure Model

\begin{tabular}{|l|c|c|c|c|}
\hline & $\begin{array}{c}\text { Original } \\
\text { Sample (O) }\end{array}$ & $\begin{array}{c}\text { T Statistics (I } \\
\text { O/STDEV |) }\end{array}$ & P Values & Note \\
\hline Consumer Based Brand Equity -> Buy Interest & $-2,971$ & 11,702 & 0,000 & Significant \\
\hline $\begin{array}{l}\text { Endorser Credibility -> Consumer Based Brand } \\
\text { Equity }\end{array}$ & 0,991 & 690,476 & 0,000 & Significant \\
\hline $\begin{array}{l}\text { Endorser credibility -> Buying interest } \\
\text { Endorser credibility -> BK Brand Equity -> } \\
\text { Buying Interest }\end{array}$ & $\begin{array}{c}3,801 \\
-2,943\end{array}$ & $\begin{array}{c}15,881 \\
11,708\end{array}$ & $\begin{array}{c}0,000 \\
0,000\end{array}$ & $\begin{array}{c}\text { Significant } \\
\text { Significant }\end{array}$ \\
\hline
\end{tabular}

Source: Processed data, 2019

\section{Mediation Effect Analysis}

Kriteria penilaian efek mediasi didasarkan pada nilai VAF:Criteria for evaluating mediation effects are based on VAF values:

1. If the value of VAF $>80 \%$, the mediating variable is full mediation,

2. If $20 \% \leq \mathrm{VAF} \leq 80 \%$, the mediating variable is partial mediation,

3. If the VAF $<20 \%$, the mediating variable is not a mediator.

with the following formula:

$$
\begin{gathered}
V A F=\frac{\text { Indirecteffect }}{\text { totaleffect }} \times 100 \% \\
V A F=\frac{11,708}{37,188} \times 100 \% \\
V A F=31.48 \%
\end{gathered}
$$

Based on the calculation of VAT value $=31.48 \%$, it shows $20 \% \leq \mathrm{VAF} \leq 80 \%$, the mediating variable is partial mediation.

SEM-PLS Analysis with Moderate Effect. Moderation effects are generally used to show the interaction between exogenous variables and moderator variables in influencing endogenous variables. Because the construct used in this study was categorical, the moderation effect was analyzed by using a multigroup with bootsrapping Approach.

\section{Discussion.}

1. The Effect of Endorser Credibility on Buying Interest
2. The endorser credibility had a significant effect $(0,000<0,05)$ on buying interest of 15,881 . Hypothesis 1 was accepted.

3. The results of this study support the finding that endorser credibility greatly influences the process of receiving messages by consumers (Hunt, 2001). Endorser credibility is one of the most important stimuli that have been used by marketers to build consumer attitudes and lead to buying interest (Samat et al., 2016). The research conducted by Samat et al., (2016) and Anam (2018) state that the credibility of endorsers has a significant effect on buying interest.

4. The Effect of Endorser Credibility on ConsumerBased Brand Equity

Endorser credibility had a significant effect $(0,000$ $<0,05$ ) on consumer-based brand equity of 690,476 . Hypothesis 2 was accepted.

The results of this study support the research conducted by Spry (2009) explainthat the direct relationship between endorsement credibility and consumer-based brand equity by using associative network memory models. The model shows that endorser support can support brand recall and brand recognition, because celebrities function as additions in memory and are associated with brand nodes. This study also analyzed the relationship between the two variables. 
The Effect of Consumer-Based Brand Equity on Buying Interests

Consumer-based brand equity had a significant effect $(0,000<0,05)$ on buying interest of 11,702 . Hypothesis 3 was accepted.

This supports the research results by Aydin and Ulengin, 2015, describing that higher brand equity influences buying interest positively (Chang and Liu 2009; Cobb-Walgren et al. 1995; Washburn and Plank 2015).

The Effect of Consumer-Based Brand Equity mediating the Relationship between Endorsement Credibility and Buying Interest

Consumer-based brand equity mediated the relationship between endorser credibility and buying interest of $31.48 \%$. Based on the calculation of VAT value $=31.48 \%$, it showed $20 \% \leq \mathrm{VAF} \leq 80 \%$, the mediating variable was partial mediation. Hypothesis 4 was accepted.

Although there has been no research that analyzes the mediating effect of endorser credibility and buying interest and is proven to not mediate sales promotion and brand positioning with purchase decisions (Yansah, Wahab, \& Shihab, 2018). However, Nasution et al (2008) research shows that brand equity has a positive impact on business performance and mediates the relationship between marketing activity and sales force performance on the performance of the business. Furthermore Clow et al (2006) state that endorsers are used in advertisements to increase the credibility and effectiveness of messages. Therefore, endorsement credibility is the determinant of consumer attitudes towards advertising that will have an impact on consumer-based brand equity which will also influence the product or brand's interest later.

5. Income Moderates the Effect of Endorsement Credibility on Buying Interests

The measurement of income moderation on the relationship between endorser credibility and buying interest had a positive effect of 2.846> 1.96 and is significant $(0.006<0.05)$. Based on the test results, income moderated the effect of endorsement credibility on buying interest. Hypothesis 5 was accepted.

The study of online buying behavior shows that higher income causes users to perceive lower implicit risks in making online purchases. Chattananon et al (2008) found that low-income consumers tend to respond positively to cause-related marketing programs, where the company contributes a percentage of its profits to a cause.

Conclusion. From the results of the research described in the previous section, there are several conclusions:

1. Endorser credibility had a significant effect on buying interest

2. Endorser credibility had a significant effect on consumer-based brand equity

3. Consumer-based brand equity had a significant effect on buying interest

4. Consumer-based brand equity mediated the relationship between endorsement credibility and buying interest

5. Income moderates the effect of endorsement credibility on buying interest.

\section{References:}

1. Aaker, D. (1991). Managing Brand Equity. New York: Free Press.

2. Aaker, D. (1997). Manajemen Ekuitas Merek. Jakarta: Spektrum.

3. Anam, B. (2018). Impact of Credibility of Celebrity Endorser on Purchase Intention and Advertising Effectiveness : Moderating Role of Experience Impact of Credibility of Celebrity Endorser on Purchase Intention and Advertising Effectiveness : Moderating Role of Experience. Journal of Marketing Communications, IV(10).

4. Amos, C., Holmes, G., \& Strutton, D. (2008). Exploring the relationship between celebrity endorser effects and advertising effectiveness. International Journal of Advertising, 27(2), 209-234.

5. Arikunto, S. (2006). Prosedur Penelitian: Suatu pendekatan Praktik. Jakarta: PT Rineka Cipta.

6. Aydin, G., \& Ulengin, B. (2015). Effect of Consumer Brand Equity on Purchase Intention: Considering Socioeconomic Status and Gender as Moderating Effects. Journal of Euromarketing, 24(2-3), 107-119.

7. Chang, H. H., \& Liu, Y. M. (2009). The impact of brand equity on brand preference and purchase intentions in the service industries. Service Industries Journal, 29(12), 1687-1706.

8. Chattananon, A., Lawley, M., Supparerkchaisakul, N., \& Lackana Leelayouthayothin. (2008). Impacts of a Thai cause-related marketing program on corporate image", International Journal of Emerging Markets, Vol. 3 Iss 4 pp. 348 - 363. International Journal for Researcher Development, 7(1), 63-83.

9. Clow, K. E., James, K. E., Kranenburg, K. E., \& Berry, C. T. (2006). The relationship of the visual element of an advertisement to service quality expectations and source credibility. Journal of Services Marketing, 20(6), 404-411.

10. Cobb-Walgren, C. J., Ruble, C. A., \& Donthu, N. (1995). Brand equity, brand preference, and purchase intent. Journal of Advertising, 24(3), 25-40.

11. Davcik, N. S., da Silva, R. V., \& Hair, J. F. (2015). Towards a unified theory of brand equity: Conceptualizations, taxonomy and avenues for future research. Journal of Product and Brand Management, 24(1), 3-17.

12. Diallo, M. F. (2012). Effects of store image and store brand price-image on store brand purchase intention: Application to an emerging market. Journal of Retailing and Consumer Services, 19(3), 360-367.

13. Dodd, M. D., \& Supa, D. W. (2011). Understanding the Effect of Corporate Social Responsibility on Consumer Purchase Intention. Public Relations Journal, 5(3), 1-19.

14. Dwivedi, A., Johnson, L. W., Mcdonald, R. E., Johnson, L. W., \& Mcdonald, R. E. (2015). Celebrity endorsement, self-brand connection and consumer-based brand equity. Journal of Product \& Brand Management, 24(5), 449-461. 
15. Engel, J. F., Blackwell, R. D., \& Miniad, P. . . (1995). Perilaku Konsumen (6th ed.). Jakarta: Binarupa Aksara.

16. Ghozali, I. (2006). Aplikasi Analisis Multivariate Dengan Program SPSS. Semarang: Badan Penerbit Universitas Diponegoro.

17. Hair, J. F., Black, W. C., Babin, B. J., \& Anderson, R. E. (2010). Multivariate Data Analysis (7th ed.). Pearson Prentice Hall.

18. Homburg, C., \& Giering, A. (2001). Personal Characteristics as Moderators of the Relationship Between Customer Satisfaction and Loyalty-An Empirical Analysis. Psychology \& Marketing, 18(1), 43-66.

19. Hunt, J. B. (2001). The Impact of Celebrity Endorsers on Consumers' Product Evaluations: A Symbolic Meaning Approach. Marketing Advances in Pedagogy, Process, and Philosophy - Annual Meeting, (1991), 1-8.

20. Kasri, R. A. (2013). Giving behaviors in Indonesia: Motives and marketing implications for Islamic charities. Journal of Islamic Marketing, 4(3), 306-324.

21. Keller, K. L. (1993). Conceptualizing, Measuring, and Managing Customer-Based Brand Equity. Journal Of Marketing, 57(1), 1-22.

22. Kim, H. W., Chan, H. C., \& Gupta, S. (2007). Value-based Adoption of Mobile Internet: An empirical investigation. Decision Support Systems, 43(1), 111-126.

23. Kotler, P., \& Keller, K. L. (2009). Manajemen Pemasaran. (B. Sabran, Ed.) (13th ed.). Jakarta: Erlangga.

24. Mittal, V., \& Kamakura, W. A. (2003). Satisfaction, Repurchase Intent, and Repurchase Behavior: Investigating the Moderating Effect of Customer Characteristics. Journal of Marketing Research, 38(1), 131-142.

25. Nasution, H., Grant, K., \& Mavondo, F. (2008). Mediating Role of Brand Equity in the Marketing - Sales and Business Performance Relationship. Journal of Business Research, (January), 1-9.

26. Ohanian, R. (1990). Construction and validation of a scale to measure celebrity endorsers' perceived expertise, trustworthiness, and attractiveness. Journal of Advertising, 19(3), 39-52.

27. Pradhan, D., Israel, D., \& Sethi, D. (2014). Celebrity endorsement: How celebrity-brand-user personality congruence affects brand attitude and purchase intention. Journal of Marketing Communications.

28. Ranaweera, C., McDougall, G., \& Bansal, H. (2005). A model of online customer behavior during the initial transaction: Moderating effects of customer characteristics. Marketing Theory, 5(1), 51-74.

29. Sam, M. F. M., \& Tahir, M. N. H. (2009). Website Quality and Consumer Online Purchase Intention of Air Ticket. International Journal of Basic \& Applied Sciences, 9(10), 4-9.

30. Samat, M. F., Ramlee, N. A. Z., Bakar, H. A., Annual, N., \& Rasid, M. F. R. M. (2016). Endorser Credibility and Its Influence on the Purchase Intention of Social Networking Sites Consumer : a Mediating Role of Attitudes Towards Sns. International Journal of Management and Applied Science, 2(12), 50-56.

31. Schiffman, \& Kanuk. (2008). Perilaku Konsumen (7th ed.). Jakarta: Indeks.

32. Schiffman, L. G., \& Kanuk, L. L. (2000). Consumer Behavior (5th ed.). New Jersey: Prentince-Hall.

33. Setiawan, L. (2018). Pengaruh Celebrity Endorsement Terhadap Purchase Intention. Manajemen Pemasaran, 12(1), 53-59.

34. Simon, C. J., \& Sullivan, M. W. (2008). The Measurement and Determinants of Brand Equity: A Financial Approach. Marketing Science, 12(1), 28-52.

35. Simon, C. J., \& Sullivan, M. W. (2008). The Measurement and Determinants of Brand Equity: A Financial Approach. Marketing Science, 12(1), 28-52.

36. SociaBuzz. (2018). The State of Influencer Marketing 2018 : Kupas Tuntas Tren Pemasaran Endorse. Jakarta.

37. Spry, A., Pappu, R., \& Cornwell, T. B. (2011b). Celebrity endorsement, brand credibility and brand equity. European Journal of Marketing, 45(6), 882-909.

38. Spears, N., \& Singh, S. N. (2004). Measuring attitude toward the brand and purchase intentions. Journal of Current Issues and Research in Advertising, 26(2), 53-66.

39. Sugiyono. (2016). Metode Penelitian Kuantitatif, Kualitatif dan R\&D. Bandung: PT Alfabet.

40. Wang, Y. S., Yeh, C. H., \& Liao, Y. W. (2013). What drives purchase intention in the context of online content services? the moderating role of ethical self-efficacy for online piracy. International Journal of Information Management, 33(1), $199-208$.

41. Washburn, J. H., \& Plank, R. E. (2015). Measuring Brand Equity: An Evaluation of a Consumer-Based Brand Equity Scale. Journal of Marketing Theory and Practice, 10(1), 46-62.

42. Wu, P. C. S., Yeh, G. Y. Y., \& Hsiao, C. R. (2011). The effect of store image and service quality on brand image and purchase intention for private label brands. Australasian Marketing Journal, 19(1), 30-39.

43. Yansah, N., Wahab, Z., \& Shihab, M. S. (2018). Analisis Brand Equity Dan Keputusan Pembelian ( Studi Pada Pegadaian Syariah Di Kota Palembang). Journal of Management and Business Review, 15(1), 33-53.

Ця робота ліцензована Creative Commons Attribution 4.0 International License 